\title{
Slow Synaptic Inhibition in Nucleus HVc of the Adult Zebra Finch
}

\author{
Marc F. Schmidt ${ }^{1}$ and David J. Perkel ${ }^{2}$ \\ ${ }^{1}$ Division of Biology, California Institute of Technology, Pasadena, California 91125, and 2Department of Neuroscience, \\ University of Pennsylvania, Philadelphia, Pennsylvania 19104-6074
}

\begin{abstract}
Nervous systems process information over a broad range of time scales and thus need corresponding cellular mechanisms spanning that range. In the avian song system, long integration times are likely necessary to process auditory feedback of the bird's own vocalizations. For example, in nucleus HVc, a center that contains both auditory and premotor neurons and that is thought to act as a gateway for auditory information into the song system, slow inhibitory mechanisms appear to play an important role in the processing of auditory information. These long-lasting processes include inhibitory potentials thought to shape auditory selectivity and a vocalization-induced inhibition of auditory responses lasting several seconds. To investigate the possible cellular mechanisms of these long-lasting inhibitory processes, we have made intracellular recordings from HVc neurons in slices of adult zebra finch brains and have
\end{abstract}

stimulated extracellularly within HVc. A brief, high-frequency train of stimuli $(50$ pulses at $100 \mathrm{~Hz}$ ) could elicit a hyperpolarizing response that lasted $2-20 \mathrm{sec}$. The slow hyperpolarization $(\mathrm{SH})$ could still be elicited in the presence of glutamate receptor blockers, suggesting that it does not require polysynaptic excitation. Three major components contribute to this activityinduced $\mathrm{SH}$ : a long-lasting $\mathrm{GABA}_{\mathrm{B}}$ receptor-mediated IPSP, a slow afterhyperpolarization requiring action potentials but not $\mathrm{Ca}^{2+}$ influx, and a long-lasting IPSP, the neurotransmitter and receptor of which remain unidentified. These three slow hyperpolarizing events are well placed to contribute to the observed inhibition of HVc neurons after singing and could shape auditory feedback during song learning.

Key words: birdsong; avian; IPSP; GABA $A_{B}$; auditory; motor
In oscine songbirds, nucleus HVc (see Fig. 1) is a crucial forebrain center for organizing singing behavior (Nottebohm et al., 1976; McCasland, 1987; Yu and Margoliash, 1996), and it contributes to generating the motor patterns for song ( $\mathrm{Vu}$ et al., 1994). HVc also receives auditory input (Fortune and Margoliash, 1995; Vates et al., 1996) and responds to playback of complex auditory stimuli (Katz and Gurney, 1981; Margoliash, 1983; Margoliash and Konishi, 1985; Lewicki, 1996). In many cases, these highly selective auditory responses are thought to occur as a consequence of complex interactions between longlasting IPSPs and intrinsic bursting properties (Lewicki and Konishi, 1995; Lewicki, 1996). An intriguing link between auditory and motor functions within HVc of adult zebra finches is the observation that auditory responses become inhibited during and after singing (McCasland and Konishi, 1981). Because auditory inputs into other areas of the song system originate from $\mathrm{HVc}$ (Williams, 1989; Doupe and Konishi, 1991; Doupe, 1993; Vicario and Yohay, 1993), inhibition of auditory inputs in this nucleus during singing may serve an important role in the temporal gating of auditory feedback into the song system. The slow IPSPs observed during auditory responses as well as the inhibition of auditory responses after singing could have profound effects on

Received Sept. 4, 1997; revised Nov. 17, 1997; accepted Nov. 19, 1997.

This work was supported by a Helen Hay Whitney Postdoctoral Fellowship to D.J.P., as well as grants from National Institutes of Health (NRSA DC00125 and RO3DC03041 to M.F.S. and RO3 DC02477 to D.J.P.). We thank Drs. Gilles Laurent, Anthony Leonardo, and Mark Konishi, as well as members of the Perkel laboratory, for helpful comments on this manuscript. We also thank Mark Konishi, in whose laboratory many of these experiments were performed, for his valuable support and advice.

Correspondence should be addressed to David J. Perkel, Department of Neuroscience, 215 Stemmler Hall, University of Pennsylvania, Philadelphia, PA 191046074 .

Copyright (C) 1998 Society for Neuroscience $\quad 0270-6474 / 98 / 180895-10 \$ 05.00 / 0$ the processing of auditory information in the adult as well as during song learning.

Long-lasting inhibition could be caused by the maintained release of a short-lasting inhibitory neurotransmitter (e.g., GABA) under the control of a long-lasting network response involving prolonged firing of action potentials (Wagner et al., 1994), or alternatively by a single long-lasting inhibitory synaptic event. Slow hyperpolarization mediated by $\mathrm{GABA}_{\mathrm{B}}$ receptor activation has been observed in many different areas of the mammalian CNS (Newberry and Nicoll, 1984; Connors et al., 1988; Dutar and Nicoll, 1988; Allerton et al., 1989). These IPSPs, however, generally last $<1$ sec (Alger, 1984; Newberry and Nicoll, 1984). Longer-lasting IPSPs that continue for many seconds have been described in only a few cases and may be mediated by 5-HT, norepinephrine, or acetylcholine (Dodd and Horn, 1983; Egan et al., 1983; Pan et al., 1989). Neuropeptides, which also can cause hyperpolarization (Pepper and Henderson, 1980; Pittman and Siggins, 1981; Williams et al., 1982), have been suggested as potential candidate neurotransmitters for IPSPs that last many seconds; a striking example of a slow peptide-mediated synaptic event has been described by Jan and Jan (1982).

We have recorded intracellularly from adult male zebra finch $\mathrm{HVc}$ neurons in brain slices to investigate whether the physiological properties within $\mathrm{HVc}$ could account for the long-lasting inhibition observed in $\mathrm{HVc}$ in vivo (McCasland and Konishi, 1981). High-frequency stimulation, approximating levels of activity observed during singing (McCasland, 1987; Yu and Margoliash, 1996), caused a slow IPSP lasting 2-20 sec. Blockade of glutamatergic excitatory transmission reduced the amplitude of the hyperpolarization but did not alter its slow time course, suggesting an intrinsically slow mechanism that did not require a 

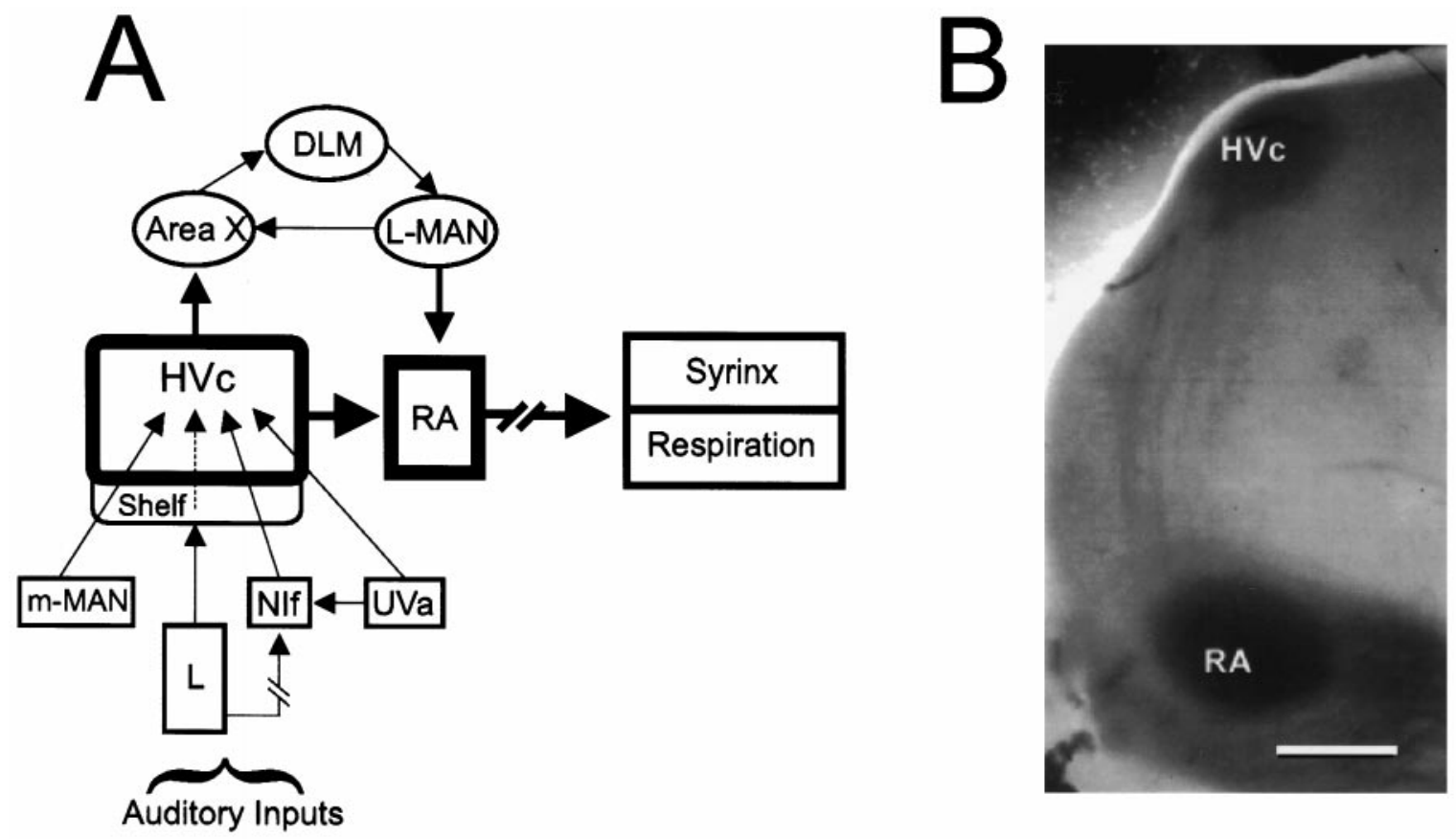

Figure 1. A, Schematic diagram of the song system showing the various connections of nucleus HVc. Nucleus $H V c$ is part of the motor pathway for song production (thick outline), sending a projection to nucleus $R A$. R A projects to brainstem motor and premotor neurons that control the Syrinx and muscles of Respiration. $\mathrm{HVc}$ also projects to Area X, which forms part of the anterior forebrain loop, a circuit essential for song learning. Auditory inputs to $\mathrm{HVc}$ originate from NIf as well as from field $L$, although field $\mathrm{L}$ inputs may reach $\mathrm{HVc}$ indirectly via the shelf surrounding the nucleus. The broken line between field L and NIf indicates that this connection involves several synapses within the auditory forebrain. HVc also receives major inputs from the forebrain nucleus $m-M A N$ and the thalamic nucleus $U V a$. $H V c$, used here as the proper name of the nucleus (Brenowitz et al., 1997), also referred to as the high vocal center (HVC); $R A$, nucleus robustus archistriatalis; $U V a$, nucleus uvaeformis; $L$, field L; NIf, nucleus interfacialis; $m$ - $M A N$, medial portion of the magnocellular nucleus of the anterior neostriatum; $L-M A N$, lateral portion of the magnocellular nucleus of the anterior neostriatum; $D L M$, medial nucleus of the dorsolateral thalamus. $B$, Photomicrograph of the experimental preparation used in this study. Parasagittal brain slices were cut through the zebra finch brain. Stimulating electrodes were placed near the posterior or anterior pole of the nucleus. Intracellular recordings were obtained from neurons in nucleus HVc, the borders of which were clearly defined even in the unstained tissue. Dorsal is up; anterior is to the right. Scale bar, $500 \mu \mathrm{m}$.

polysynaptic network. Pharmacological dissection of this hyperpolarization revealed at least three components of the inhibition.

\section{MATERIALS AND METHODS}

Preparation of slices and electrophysiological recording. Adult zebra finches (Taeniopygia guttata) were obtained from a breeding colony at Caltech as well as from local suppliers near Los Angeles and Philadelphia. Slices were prepared as described previously (Mooney, 1992; Perkel and Nicoll, 1993). Briefly, birds were anesthetized with halothane or isoflurane and decapitated. The brain was removed rapidly and placed in ice-cold artificial cerebrospinal fluid (ACSF) that had been bubbled with $95 \%$ $\mathrm{O}_{2} / 5 \% \mathrm{CO}_{2}$. Composition of the ACSF was (in mM): $\mathrm{NaCl} 134, \mathrm{KCl} 2.5$, $\mathrm{NaH}_{2} \mathrm{PO} 41, \mathrm{NaHCO}_{3} 26$, D-glucose $12, \mathrm{CaCl}_{2} 2.5, \mathrm{MgSO}_{4} 1.5$. The brain was cut midsagittally with a razor blade and parasagittal slices $(400 \mu \mathrm{m}$ thick) were prepared using a vibrating microtome. Slices were stored at room temperature on porous membrane (Nucleopore, Cambridge, MA) at the interface of ACSF and humidified $95 \% \mathrm{O}_{2} / 5 \% \mathrm{CO}_{2}$ or submerged in bubbled ACSF. For recording, a slice was transferred to a submersion chamber where it was superfused with pregassed ACSF.

Intracellular electrodes were filled with $4 \mathrm{M}$ potassium acetate and had DC resistances of $70-140 \mathrm{M} \Omega$. Stable intracellular recordings were routinely obtained from neurons in nucleus $\mathrm{HVc}$, the borders of which were clearly defined even in the unstained tissue. Resting potential and input resistance were closely monitored and remained stable for the duration of the recording, commonly $2-5 \mathrm{hr}$. One or more stainless steel bipolar stimulating electrodes (impedance 2-5 $\mathrm{M} \Omega$ ) were placed within $\mathrm{HVc}$, usually near the posterior or anterior pole (Fig. $1 B$ ). We stimulated somata and fibers within $\mathrm{HVc}(100 \mu \mathrm{sec}$ duration; constant voltage, 5-60 $\mathrm{V})$ because input pathways to $\mathrm{HVc}$ are not segregated well enough to stimulate one specifically. Moreover, stimulation outside of $\mathrm{HVc}$ would likely cause antidromic activation of $\mathrm{HVc}$ outputs, which exit across a broad region (Nottebohm et al., 1982).
Signals were amplified using an Axoclamp 2A (Axon Instruments, Foster City, CA), low-pass filtered, and digitized at twice the filter cut-off frequency. Intracellular records are presented here as the average of two to three consecutive traces. Analysis included fitting a single exponential function to the decay phase of a synaptic potential using a least-squares algorithm. Average values of response amplitudes or best-fit time constants are presented as the mean $\pm \mathrm{SD}$. The Student's $t$ test, paired or unpaired, was used as indicated.

Materials. Chemicals were obtained from Sigma (St. Louis, MO), except as noted. DMSO was purchased from Fisher Scientific (Pittsburgh, PA). The AMPA glutamate receptor antagonist 6-cyano-7nitroquinoxaline-2,3-dione (CNQX), the NMDA glutamate receptor antagonist DL-2-amino-5-phosphonovaleric acid (APV), and the opiate antagonist naloxone were obtained from Research Biochemicals (Natick, MA). The $\mathrm{GABA}_{\mathrm{B}}$ receptor antagonist CGP 35348 was a gift from CIBA-Geigy (Basel, Switzerland). Except as noted, all drugs were added to the superfusion medium by dilution of a stock solution made in water. Stock solutions of CNQX were made in DMSO, resulting in a final concentration of DMSO of $0.1-0.2 \%$, which when added alone did not affect any of the responses observed. Bicuculline methiodide (BMI) was dissolved directly into the ACSF.

\section{RESULTS}

\section{High-frequency stimuli in HVc elicit a slow depolarization/hyperpolarization sequence lasting many seconds}

We recorded intracellularly from $\mathrm{HVc}$ neurons and activated synaptic inputs via a stimulating electrode placed within nucleus HVc (Fig. 1B). In selecting a stimulation pattern, we were guided by reported high firing rates observed during 

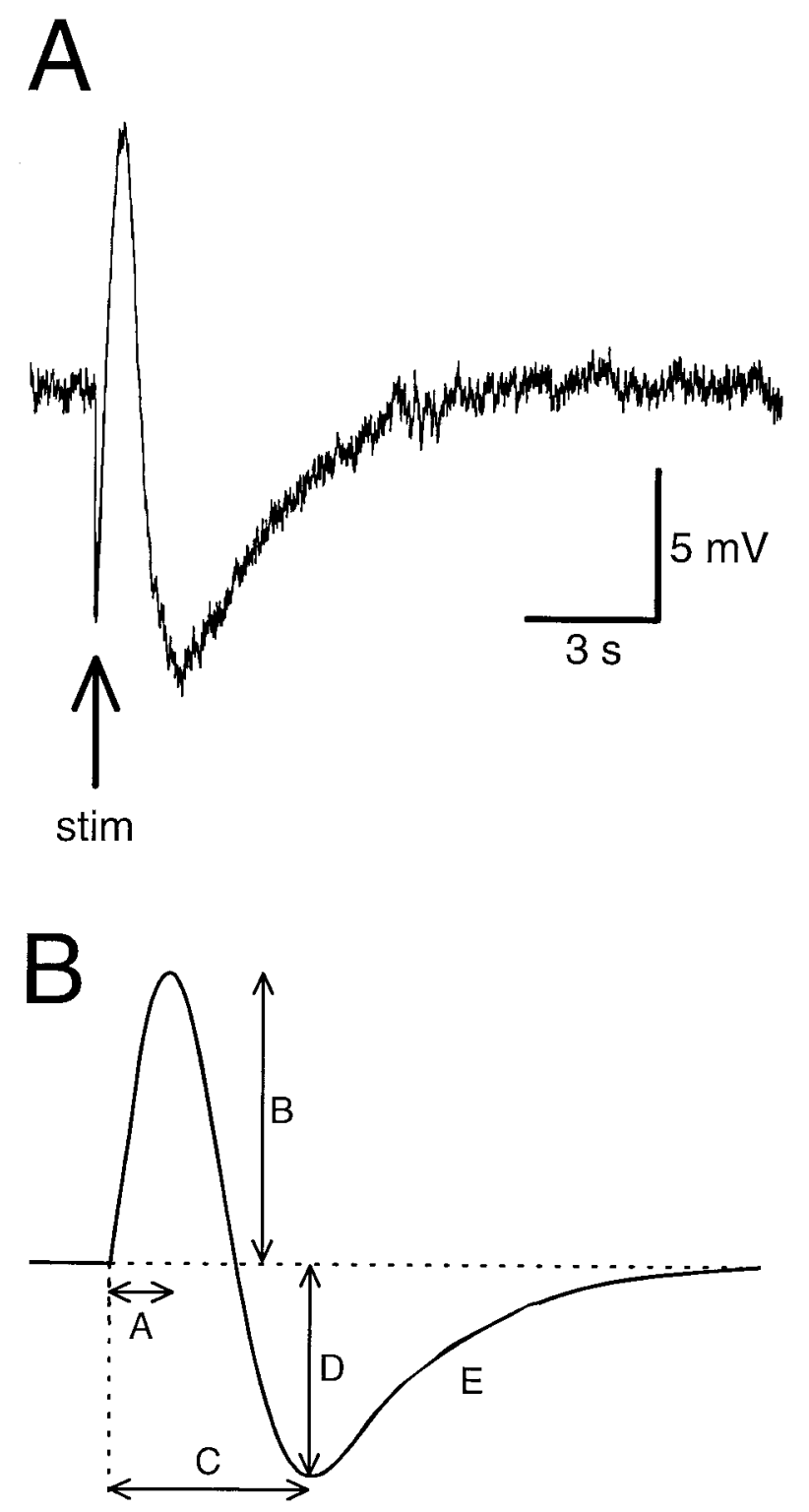

Figure 2. Slow depolarizing/hyperpolarizing sequence after repetitive synaptic stimulation of an $\mathrm{HVc}$ neuron. $A$, This sample trace illustrates the potential change caused by stimulating within nucleus $\mathrm{HVc}$ at $100 \mathrm{~Hz}$ for $0.5 \mathrm{sec}$. Such stimulation caused this HVc neuron to exhibit a slow depolarization followed by a long-lasting hyperpolarization. In this case the decay time constant of the hyperpolarization was $2.6 \mathrm{sec}$, and the resting membrane potential was $-65 \mathrm{mV}$. Arrow indicates onset of stimulation. $B$, This schematic representation of the slow depolarizing/hyperpolarizing sequence illustrates how waveform parameters were measured. $A$, Time-to-peak for the depolarization $B$. Amplitude of peak depolarization. $C$, Time-to-peak hyperpolarization. $D$, Amplitude of peak hyperpolarization. E, Decay time constant of the hyperpolarization. See Table 1 for recorded values.

singing (McCasland, 1987; Yu and Margoliash, 1996). Single high-frequency trains of synaptic stimuli $(50$ pulses; $100 \mathrm{~Hz})$ caused a slow depolarization followed by an unusually slow hyperpolarization ( $\mathrm{SH}$ ) lasting up to $20 \mathrm{sec}$ (Figs. $2 A, 3 C$ ). The hyperpolarization was often punctuated by small depolarizing deflections (Fig. 2A). The overall amplitude of the slow depolarization/hyperpolarization $(\mathrm{SDH})$ appeared to depend on the number of pulses in the stimulus train (Fig. $3 A$ ). Although we have not performed a systematic analysis of the stimulus
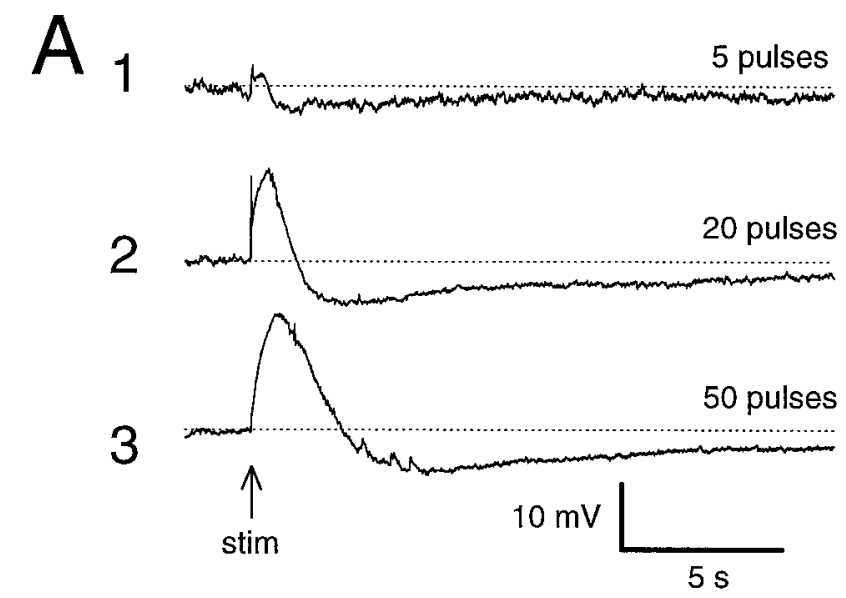

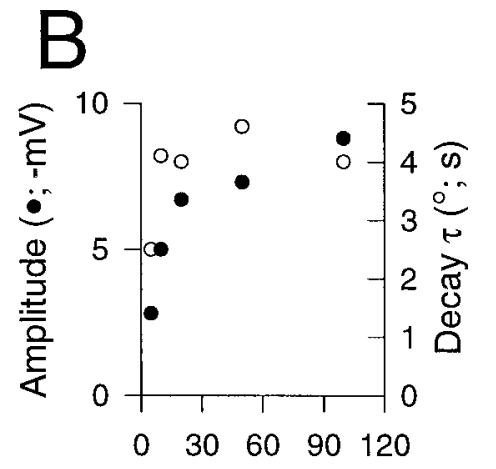

Number of stimuli

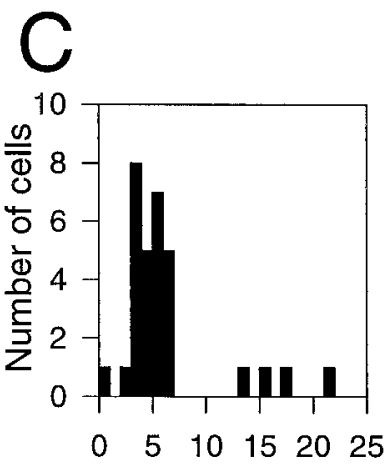

Time constant (s)
Figure 3. Effect of stimulation pattern on amplitude and time course of the $\mathrm{SH} . A, \mathrm{HVc}$ neurons were subjected to different numbers of stimuli ( $A 1,5$ pulses; $A 2,20$ pulses; $A 3,50$ pulses) delivered at $100 \mathrm{~Hz}$. The amplitude and the time course of both the slow depolarization and the hyperpolarization were directly dependent on the number of pulses used in the stimulus. Dotted line indicates the resting potential for the cell illustrated $(-58 \mathrm{mV}) . B$, Peak amplitude and decay time constant of the $\mathrm{SH}$ component varied with the number of stimuli. Peak amplitude (filled circles) of the $\mathrm{SH}$ increased rapidly with the number of stimuli reaching $80 \%$ of maximum with a 20 -pulse stimulus. Decay time constant (open circles) increased from 5 to 10 pulses and then leveled out around $4 \mathrm{sec}$. $C$, Histogram for all cells recorded showing the range of decay time constants $(\tau)$ for the $\mathrm{SH}$ obtained using the standard 50-pulse stimulation. Time constants tended to cluster around $5 \mathrm{sec}$.

parameters, in four of four neurons, the $\mathrm{SH}$ amplitude was near maximal with a stimulus train of $20-50$ pulses (Fig. $3 B$ ). Its slow time course was apparent after only five stimuli (Fig. $3 B$ ). We were able to elicit an SDH in $66 \%$ of the cells tested (57/86 neurons). This percentage should be viewed as a rough approximation because it is subject to positioning of the stimulating electrode as well as sampling bias. In cells in which a single train gave rise to an SDH, a similar SDH was also elicited by a more complex stimulus consisting of five pulses at $100 \mathrm{~Hz}$ repeated five times at $5 \mathrm{~Hz}$.

We measured the components of the SDH illustrated in Figure $2 B$, and the values are summarized in Table 1 . In most of the cells recorded (26/31) (Fig. 3C), the decay time constant fell within the range of 2.6-6.9 sec, with a mean of $4.8 \pm 1.3 \mathrm{sec}$ for those 26 neurons. One outlier had a decay time constant of $639 \mathrm{msec}$, whereas four others fell in the range of 13-21 sec. 
Table 1. Waveform parameters for the slow IPSP elicited in response to tetanic stimulation

\begin{tabular}{|c|c|c|c|c|c|}
\hline Condition & $\begin{array}{l}\text { (A) Time to peak } \\
\text { depolarization } \\
\text { (msec) }\end{array}$ & $\begin{array}{l}\text { (B) Peak depolar- } \\
\text { ization }(\mathrm{mV})\end{array}$ & $\begin{array}{l}\text { (C) Time to peak } \\
\text { hyperpolarization } \\
\text { (msec) }\end{array}$ & $\begin{array}{l}\text { (D) Peak hyperpo- } \\
\text { larization }(\mathrm{mV})\end{array}$ & $\begin{array}{l}\text { (E) Decay time } \\
\text { constant (sec) }\end{array}$ \\
\hline Control & $300 \pm 229$ & $9.8 \pm 7.8$ & $2600 \pm 1200$ & $8.3 \pm 3.2$ & $6.3 \pm 4.6$ \\
\hline CNQX/APV & $284 \pm 237$ & $7.7 \pm 3.5^{*}$ & $\begin{aligned} 801 & \pm 1000^{* * *} \\
2600 & \pm 1100\end{aligned}$ & $3.3 \pm 1.7^{*}$ & $4.4 \pm 2.3$ \\
\hline$+\mathrm{BMI}$ & None & None & $1200 \pm 600^{*}$ & $7.1 \pm 3.9^{* * *}$ & $5.1 \pm 4.9$ \\
\hline
\end{tabular}

*Significant difference from value measured in control conditions $(p<0.05)$.

**First value for all cells to which CNQX and APV were applied $(n=20)$. Second value for those cells held for BMI application $(n=8)$.

*** Significant difference from value measured in the presence of CNQX and APV $(p<0.02)$.

\section{The slow depolarization/hyperpolarization can occur with blocked network excitation}

To test whether the SDH response resulted from persistent polysynaptic network activity, we blocked excitatory neurotransmission pharmacologically. Vu and Lewicki (1994) have reported blockade of EPSCs in HVc by ionotropic glutamate receptor antagonists. We used $20 \mu \mathrm{M}$ CNQX to block AMPA receptors (Honoré et al., 1988) and $100 \mu \mathrm{M}$ APV to block NMDA receptors (Davies et al., 1981). This combination of antagonists blocked monosynaptic EPSPs evoked by single-shock stimulation (Fig. $4 A$ ) and almost always (19/20) reduced the amplitude of the SDH response (Fig. $4 B$ ). The overall effect of blocking glutamatergic transmission on the SDH response was quite variable. The depolarization was often eliminated $(9 / 14)$, whereas in the remaining five cells it was reduced to $43 \pm 13 \%$ of its control value (Table $1)$. The time-to-peak depolarization was unchanged with ionotropic glutamatergic transmission blocked $(p>0.89)$. The effect of CNQX and APV on the hyperpolarization amplitude was particularly variable. The peak amplitude in the presence of the blockers averaged $60 \pm 53 \%$ of control $(n=20$; range, $2-140 \%)$ (Fig. 4C). The time-to-peak hyperpolarization was shortened. Despite the changes in the amplitude values, the addition of CNQX and APV did not significantly change the decay time constant of the SH ( $p>0.45$; paired $t$ test). Because blockade of excitatory amino acid receptors should eliminate polysynaptic responses, these results suggest that glutamatergic excitatory connections remaining within the slice contribute significantly to both the slow depolarization and hyperpolarization responses. However, because a substantial portion of the $\mathrm{SH}$ remained after blockade of ionotropic glutamate receptors, these data also suggest that the hyperpolarizing component of the SDH may result from direct activation of inhibitory neurons. Moreover, the time course of the SH appears not to depend on the activation of an extensive network of excitatory glutamatergic connections.

\section{The slow depolarizing response is mediated by activation of $\mathrm{GABA}_{\mathrm{A}}$ receptors}

To characterize the slow hyperpolarizing portion of the SDH, we attempted to block the initial slow depolarizing phase of the response. Previous studies have shown that $\mathrm{GABA}_{\mathrm{A}}$ receptor activation, which is normally hyperpolarizing, can become depolarizing when neurons are stimulated at high frequency (Andersen et al., 1980; Alger and Nicoll, 1982; Staley et al., 1995). The addition of the $\mathrm{GABA}_{\mathrm{A}}$ receptor antagonist BMI $(40 \mu \mathrm{M})$ (Curtis et al., 1970; Newberry and Nicoll, 1984) to neurons exhibiting a substantial SDH in the presence of CNQX and APV completely blocked the slow depolarizing response in all cases tested (Fig. 5) $(n=8)$. Blockade by BMI left a hyperpolarization that sometimes, but not always, appeared to have two decay phases. The slow phase measured in the presence of CNQX, APV, and BMI had a decay time constant unchanged from that measured before the addition of BMI $(n=8 ; p>0.3$; paired $t$ test). Although the decay time course of the $\mathrm{SH}$ remained unchanged, the peak amplitude during $\mathrm{GABA}_{\mathrm{A}}$ receptor blockade was larger ( $n=8 ; p<0.05$; paired $t$ test) and occurred sooner after stimulation $(n=8 ; p<0.05$; paired $t$ test $)$ than in the presence of just CNQX and APV (see Table 1).

When the membrane potential was shifted by injecting DC current, the extrapolated reversal potential was approximately $-95 \mathrm{mV}$ (data not shown), suggesting the $\mathrm{SH}$ is mediated by an increase in potassium conductance. In two cases, the apparent reversal potential was shifted to a depolarized level when the external potassium concentration was raised (data not shown). A more detailed biophysical analysis of the $\mathrm{SH}$ will require voltageclamp techniques with better control of the postsynaptic membrane potential.

\section{Contribution of a long-lasting AHP to the slow hyperpolarization}

The $\mathrm{SH}$ was in some cases likely to be purely synaptic in nature because it could be elicited in the absence of stimulus-induced antidromic action potentials $(n=6)$ (Fig. $2 A)$. In many cases, however, despite the presence of glutamate receptor blockade, stimulation within $\mathrm{HVc}$ produced action potentials and created the possibility that a portion of the hyperpolarization was caused by an action potential-induced slow afterhyperpolarization (sAHP). These action potentials were not unexpected, given the high degree of axonal arborization within HVc (Katz and Gurney, 1981; Nottebohm et al., 1982; Nixdorf et al., 1989) and were likely antidromic in nature because they (1) had rapid onset times, (2) persisted in the presence of glutamatergic receptor antagonists, (3) persisted in the presence of hyperpolarizing current, and (4) were not blocked by the calcium channel blocker $\mathrm{CdCl}_{2}$ $(100 \mu \mathrm{M})$, which eliminated all synaptic transmission.

Slow AHPs in nucleus HVc could be elicited by direct current injection (Kubota and Saito, 1991) (Fig. 6) and were characterized by an initial, rapidly decaying phase followed by a very slow component, the time course of which resembled the decay time constant of the $\mathrm{SH}$ observed after extracellular stimulation within HVc (compare Fig. 5 and Fig. 6). The decay time constant of the two hyperpolarizations was directly compared in 15 cells. The value was $5.4 \pm 3.9 \mathrm{sec}$ for the $\mathrm{SH}$ and $4.3 \pm 2.4 \sec (n=15 ; p>0.07 ; t$ test $)$ for the sAHP. Thus, on the basis of the time course, in cases in which extracellular stimulation caused antidromic action potentials the SAHP could have contributed to the SH.

In an attempt to discriminate between the synaptic component of the SH and the sAHP, we sought a pharmacological means of 


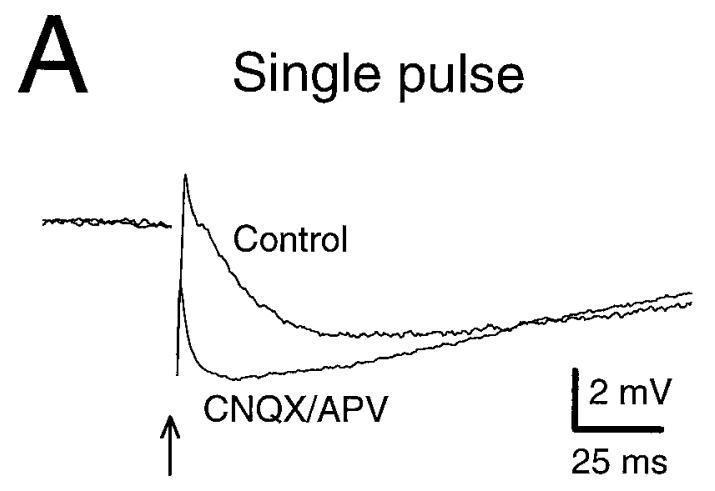

B

\section{Train}
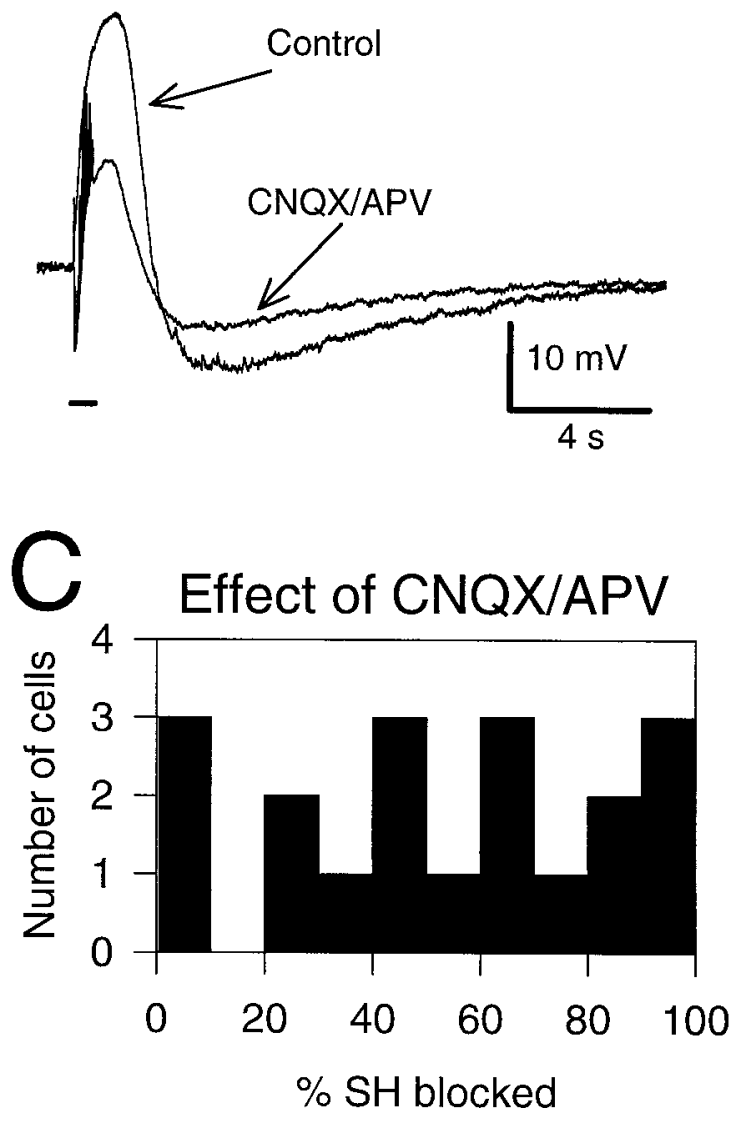

Figure 4. Effect of ionotropic glutamate receptor antagonists on synaptically evoked potentials in nucleus HVc. $A$, A single-shock stimulus typically elicited a rapid onset EPSP followed by an IPSP lasting several hundred milliseconds. Stronger stimulation could elicit an action potential. Bath application of the glutamate antagonists CNQX $(20 \mu \mathrm{M})$ and APV $(100 \mu \mathrm{M})$ blocked the EPSP and preserved the slow IPSP. $B$, Bath application of CNQX/APV generally had a wide range of effects on the time course and amplitude of the $\mathrm{SH}$ elicited by a fast train of stimuli $(50$ pulses at $100 \mathrm{~Hz})$. These effects ranged from partial decrease in amplitude of the hyperpolarization to nearly complete blockade. This sample trace illustrates a typical example (different cell from $A$ ), in which the amplitude of the $\mathrm{SH}$ is decreased by $\sim 40 \%$ after blockade of excitatory transmission. $C$, This histogram illustrates the range of effects observed after the addition of CNQX/ APV. Although addition of glutamate receptor antagonists always reduced the amplitude of the $\mathrm{SH}$, the overall level of reduction was quite variable. Percent reduction of the $\mathrm{SH}$ (measured at peak amplitude) ranged from 0 to $98 \%$, with a median reduction near $50 \%$. Two cells in which the $\mathrm{SH}$ grew after application of CNQX and APV are represented as $0 \%$ blockade here.

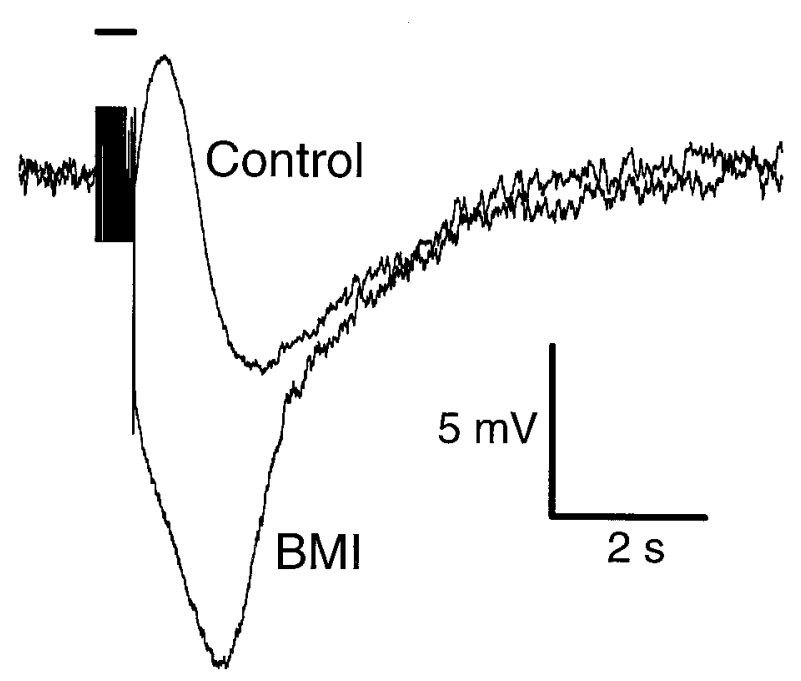

Figure 5. Effect of the $\mathrm{GABA}_{\mathrm{A}}$ receptor antagonist bicuculline methiodide $(B M I)$ on the depolarizing phase of the synaptically evoked slow depolarization/hyperpolarization sequence. High-frequency stimulation (50 pulses at $100 \mathrm{~Hz}$ ) was used to obtain an $\mathrm{SDH}$ sequence (Control) in the presence of CNQX $(20 \mu \mathrm{M})$ and APV $(100 \mu \mathrm{M})$. Addition of BMI (40 $\mu \mathrm{M})$ in the continued presence of CNQX and APV completely blocked the depolarizing phase of the synaptic response. This blockade of a depolarizing response by BMI was not unexpected, given previous reports showing that stimulation at high frequency can cause $\mathrm{GABA}_{\mathrm{A}}$ receptormediated events to become depolarizing (see Results). The peak amplitude of the hyperpolarization significantly increased after addition of $\mathrm{BMI}$, suggesting that the reversed $\mathrm{GABA}_{\mathrm{A}}$ depolarizing phase was masking part of the $\mathrm{SH}$. On average, the slow decay time constant remained unchanged in the presence of BMI. In this case the decay time constants were $1.8 \mathrm{sec}$ (Control) and $2.2 \mathrm{sec}(B M I)$. The rise to peak hyperpolarization in the presence of BMI often had a characteristic linear shape.

selectively blocking the sAHP. In agreement with Kubota and Saito (1991), we found that in nucleus $\mathrm{HVc}$, the slow phase of the sAHP is insensitive to the broad-spectrum calcium channel blocker cadmium (Fig. $7 A$ ), suggesting that the conductance is different from that of calcium-dependent sAHPs observed in other systems (for review, see Sah, 1996). This sAHP was also insensitive (Fig. $7 B)$ to either norepinephrine (NE) $(10 \mu \mathrm{M} ; n=$ $5)$, or the cholinergic agonist carbachol $(10 \mu \mathrm{M} ; n=3)$, both known modulators of calcium-dependent sAHPs (Nicoll, 1988). We were able to block this sAHP, however, by adding the sodium channel blocker tetrodotoxin $(1 \mu \mathrm{M} ; n=7)$ (Fig. $7 C)$ (Kubota and Saito, 1991). This result is consistent with the hypothesis that the sAHP present in H Vc neurons is generated by sodium-dependent activation of a potassium conductance (Kubota and Saito, 1991), although other possibilities cannot be excluded. Unfortunately, because TTX would block both sAHP and synaptic-mediated events, this pharmacological agent could not be used to block selectively the sAHP contribution to the SH. To circumvent this problem, we attempted to block sodium channels with the intracellular sodium channel blocker QX-314. This drug did block the action potential-mediated sAHP. Unfortunately, QX-314 also blocked $\mathrm{GABA}_{\mathrm{B}}$ receptor-mediated inhibition (Andrade, 1991) ( $n=3$, data not shown) and could not be used here to remove the sAHP selectively.

These results indicate that $\mathrm{HVc}$ neurons contain a slow, TTXsensitive SAHP with a time course similar to the SH observed after synaptic stimulation. Although we were unable to block the sAHP selectively, we exploited its lack of dependence on calcium. 

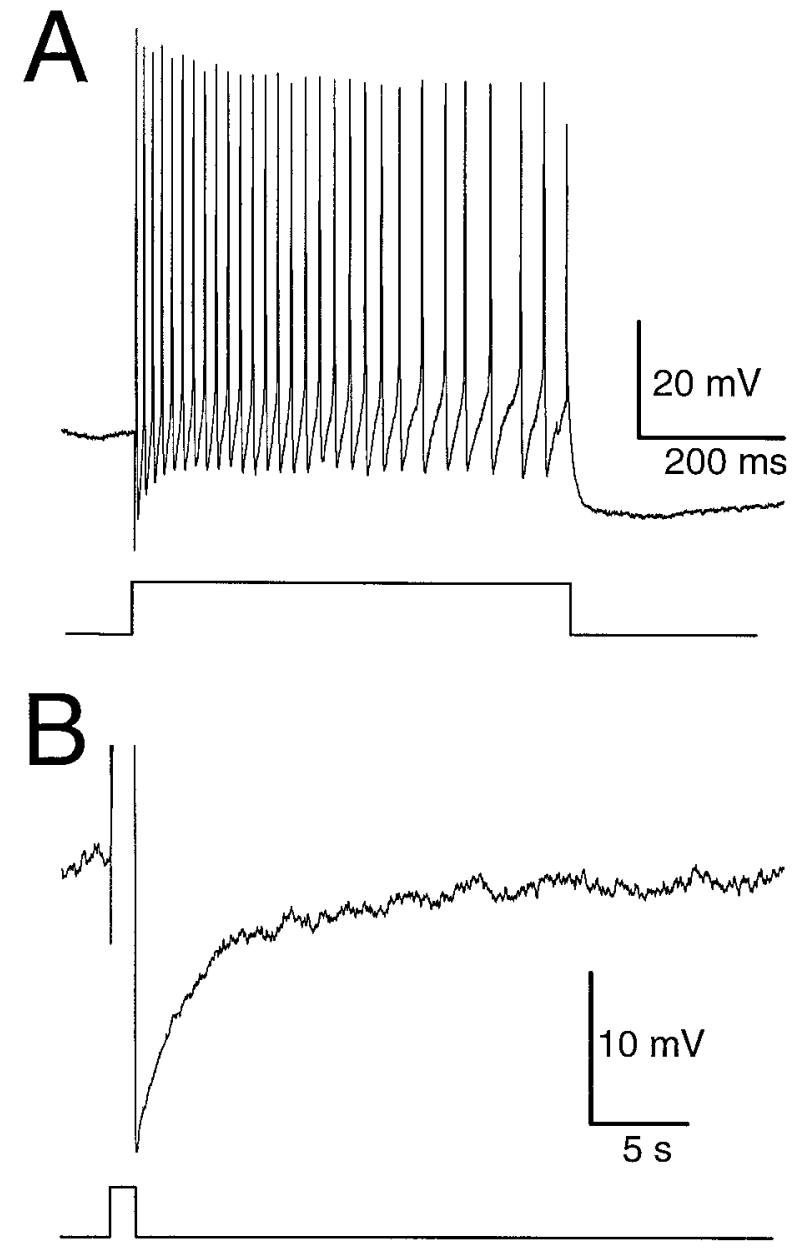

Figure 6. Depolarizing current pulses cause a slow afterhyperpolarization (sAHP). $A$, An example of rapid action potentials elicited by direct current injection into an $\mathrm{HVc}$ neuron $(0.8 \mathrm{nA}, 1 \mathrm{sec})$. $B$, Such current injection caused an afterhyperpolarization with a relatively short time to peak but slow decay time constant $(4.1 \mathrm{sec})$. Resting membrane potential $=-63 \mathrm{mV}$.

We thus further characterized the SH by separating intrinsic from synaptic components using sensitivity of synaptic transmitter release to cadmium (see Results).

\section{Contributions of $\mathrm{GABA}_{\mathrm{B}}$ receptor activation to the slow hyperpolarization}

Most neurons contain a multiplicity of potassium channels, the activation of which can lead to hyperpolarization (Nicoll, 1988). In many cases, activation of $\mathrm{GABA}_{\mathrm{B}}$ receptors by exogenous application of baclofen causes a hyperpolarization via increased potassium conductance. In hippocampal pyramidal cells, synaptically released GABA acts on $\mathrm{GABA}_{\mathrm{B}}$ receptors to cause slow IPSPs that last hundreds of milliseconds (Dutar and Nicoll, 1988). To assess whether $\mathrm{HVc}$ neurons are capable of responding to $\mathrm{GABA}_{\mathrm{B}}$ receptor activation, we first perfused slices with the $\mathrm{GABA}_{\mathrm{B}}$ receptor agonist baclofen $(30 \mu \mathrm{M})$. Bath application of this agonist caused a marked hyperpolarization in every cell examined (Fig. $8 A)(11.0 \pm 3.8 \mathrm{mV} ; n=14)$. This hyperpolarization was associated with a decrease in input resistance, consistent with the increase in potassium conductance observed in other cell types (Fig. 8B) (Newberry and Nicoll, 1984; Gahwiler and Brown, 1985; Nicoll, 1988). When the membrane potential

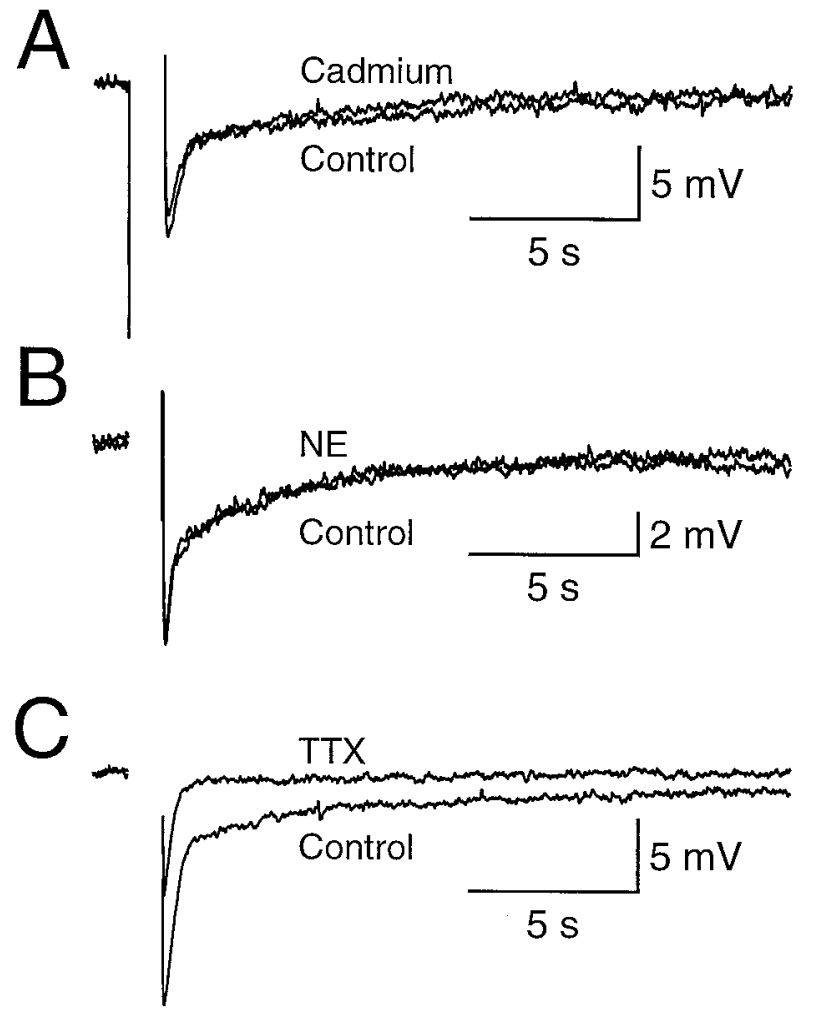

Figure 7. Properties of the sAHP in HVc neurons. A, A direct depolarizing current pulse $(0.5-2.0 \mathrm{nA} ; 1 \mathrm{sec})$ gave rise to a very slowly decaying sAHP. Such depolarization typically elicited 30-40 action potentials during the pulse (not shown). Application of the $\mathrm{Ca}^{2+}$ channel blocker $\mathrm{CdCl}_{2}(100 \mu \mathrm{M})$, known to block sAHPs in other systems, had no effect on either the duration or amplitude of the sAHP. $B$, Norepinephrine (10 $\mu \mathrm{M}$ ), which blocks the sAHP in other cell types (Madison and Nicoll, 1982), did not affect the sAHP in HVc. $C$, Bath application of the sodium channel blocker tetrodotoxin $(T T X)(1 \mu \mathrm{M})$ completely blocked the slow phase of the sAHP.

was returned to control levels by injection of steady depolarizing current, input resistance was still reduced (Fig. $8 B_{1}, B_{3}$ ), indicating that the conductance change was not merely secondary to the change in potential.

In the presence of the $\mathrm{GABA}_{\mathrm{B}}$ receptor antagonist CGP 35348 $(500 \mu \mathrm{M})$ (Olpe et al., 1990), baclofen did not significantly hyperpolarize HVc neurons $(-0.6 \pm 1.9 \mathrm{mV} ; n=7 ; p>0.35)$. In six cells, responses to baclofen were measured in the presence and absence of CGP 35348. The antagonist reduced the baclofen response by $91 \pm 20 \%(n=6)$. When baclofen was added after washout of CGP 35348, neurons responded with the characteristic hyperpolarization (Fig. 9) $(n=4 / 4)$. These findings validate baclofen and CGP 35348 as selective GABA $_{\mathrm{B}}$ receptor compounds in this avian system and indicate that $\mathrm{HVc}$ neurons express $\mathrm{GABA}_{\mathrm{B}}$ receptors coupled to potassium channels.

To investigate directly the role of $\mathrm{GABA}_{\mathrm{B}}$ receptors in generating the slow synaptic hyperpolarization, we examined the effect of CGP 35348 on the SH elicited in the presence of CNQX, APV, and BMI. Bath application of CGP $35348(500 \mu \mathrm{M})$ produced quite variable effects (Fig. $10 B$ ) ranging from no effect to nearly complete blockade of the $\mathrm{SH}$ (Fig. $10 A$ ). The average reduction in peak amplitude of the SH was $44 \pm 27 \%(n=19)$. These results demonstrate that a substantial component of the $\mathrm{SH}$ can be accounted for by activation of $\mathrm{GABA}_{\mathrm{B}}$ receptors and suggest that GABA is able to produce IPSPs that last many seconds. The 


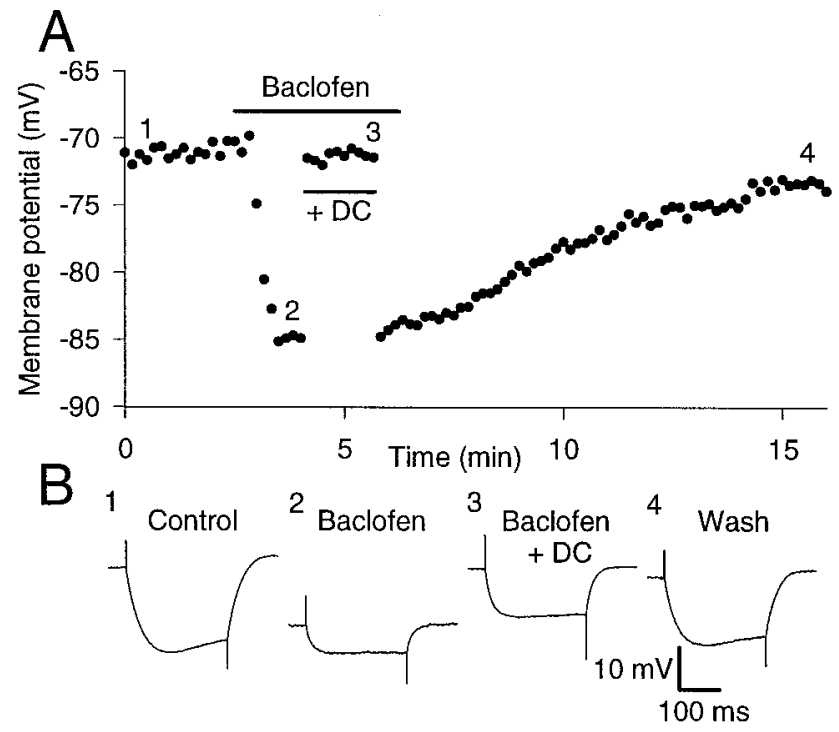

Figure 8. Effect of the $\mathrm{GABA}_{\mathrm{B}}$ receptor agonist baclofen on $\mathrm{HVc}$ neurons. $A$, Bath application of baclofen $(30 \mu \mathrm{M})$ caused a reversible hyperpolarization associated with a decrease in input resistance. Input resistance was monitored by passing $300 \mathrm{msec}$ current pulses $(-0.1 \mathrm{nA})$ every 5-20 sec (see B1-B4). Input resistance remained decreased even after the membrane potential was shifted back to the original resting potential by DC depolarization $(+D C ; B 3)$. These results suggest that baclofen causes an increase in potassium conductance, a commonly observed effect of activating $\mathrm{GABA}_{\mathrm{B}}$ receptors in many other systems.
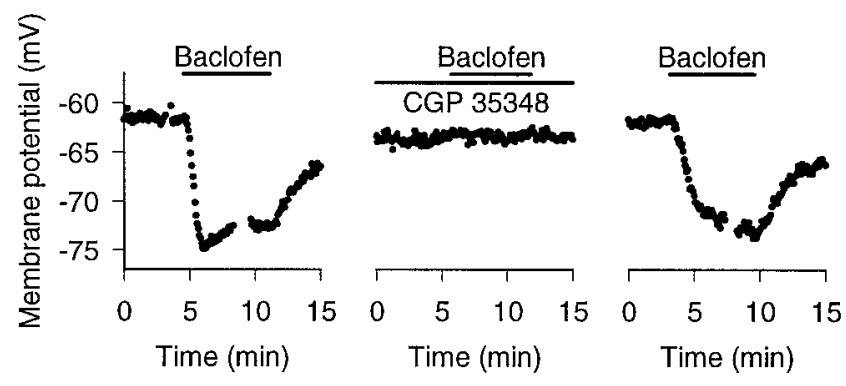

Figure 9. Effect of the $\mathrm{GABA}_{\mathrm{B}}$ receptor antagonist CGP 35348 on the hyperpolarizing action of baclofen. To test the effect of CGP 35348 on $\mathrm{HVc}$ neurons, neurons were first subjected to bath application of baclofen $(30 \mu \mathrm{M})$ to ensure that baclofen produced a hyperpolarizing response (left panel). After a recovery period of $20 \mathrm{~min}$ the membrane potential returned to near the original resting potential. In the presence of CGP $35348(500 \mu \mathrm{M})$, baclofen did not affect the membrane potential (middle panel). The small difference in membrane potential between the left and middle panels was not a common observation. Addition of baclofen after washout of the antagonist produced a normal hyperpolarizing response (right panel). Blank portions of the traces during baclofen addition indicate time when the membrane potential was returned to the original resting potential (see Fig. 8). These points were omitted for clarity. All traces were obtained from the same neuron over a period of $1 \mathrm{hr}$.

variable effect of the $\mathrm{GABA}_{\mathrm{B}}$ antagonist suggests that $\mathrm{GABA}_{\mathrm{B}}$ receptors may contribute a different fraction of the $\mathrm{SH}$ in different neurons.

\section{A GABA $_{B}$ receptor-independent IPSP contributes to the slow hyperpolarization}

In many cases, a residual $\mathrm{SH}$ resisted blockade by the mixture of CNQX, APV, BMI, and CGP 35348. In an attempt to block the remaining synaptically mediated hyperpolarization, we applied a mixture of receptor antagonists implicated in slow hyperpolariz-
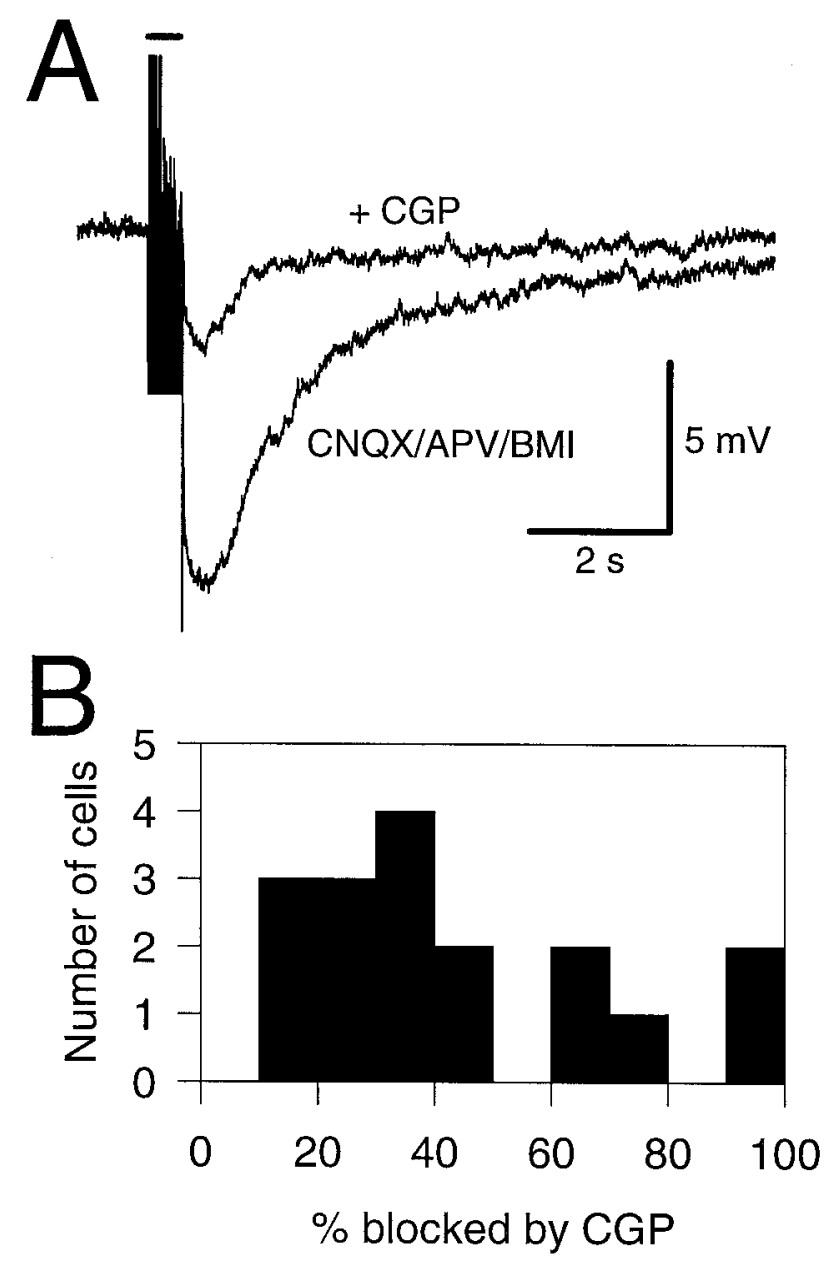

Figure 10. Effect of the $\mathrm{GABA}_{\mathrm{B}}$ receptor antagonist CGP 35348 on the stimulus-induced $\mathrm{SH}$. $A$, A brief, high-frequency stimulus train (50 pulses at $100 \mathrm{~Hz}$; indicated by the horizontal bar above the trace) was used to elicit a long-lasting SH in the presence of CNQX $(20 \mu \mathrm{M})$, APV $(100 \mu \mathrm{M})$, and BMI $(40 \mu \mathrm{M})$. After several stable stimulation trains (elicited every 2 $\min )$, CGP $35348(500 \mu \mathrm{M})$ was added to the mixture of drugs. In this particular example, addition of the $\mathrm{GABA}_{\mathrm{B}}$ receptor antagonist blocked a large portion of the $\mathrm{SH}$. The nature of the remaining hyperpolarization could have been caused by a synaptically mediated IPSP or alternatively by an SAHP, because stimulation caused antidromic firing in this neuron. $B$, The effect of CGP 35348 on the SH was quite variable across $\mathrm{HVc}$ neurons. This histogram illustrates that nearly all neurons were affected by addition of the $\mathrm{GABA}_{\mathrm{B}}$ receptor antagonist. A large proportion of neurons $(64 \%)$ had their SH reduced by $>30 \%(n=11 / 17)$.

ing responses. The addition of this mixture, consisting of antagonists to opioid receptors (naloxone, $500 \mu \mathrm{M}$ ), muscarinic acetylcholine receptors (atropine, $10 \mu \mathrm{M}$ ), or $\alpha_{2}$ noradrenergic receptors (yohimbine, $20 \mu \mathrm{M}$ ) was without effect in reducing either the magnitude or the time course of the hyperpolarization ( $n=3$; data not shown).

To assess the relative contribution of synaptic transmission to this residual $\mathrm{SH}$, we applied the calcium channel blocker $\mathrm{CdCl}_{2}$, which blocks transmitter release but not the sAHP (Fig. 7A). The $\mathrm{SH}$ was elicited using our standard stimulation protocol in the presence of antagonists to glutamate and $\mathrm{GABA}_{\mathrm{A}}$ receptors (CNQX, APV, and BMI). After several stable baseline traces (Fig. $11 A$ ), the $\mathrm{GABA}_{\mathrm{B}}$ component of the $\mathrm{SH}$ was removed by adding CGP 35348 (Fig. 11B). After confirming that the antagonistic effect of CGP 35348 had stabilized, $\mathrm{CdCl}_{2}(100 \mu \mathrm{M})$ was 


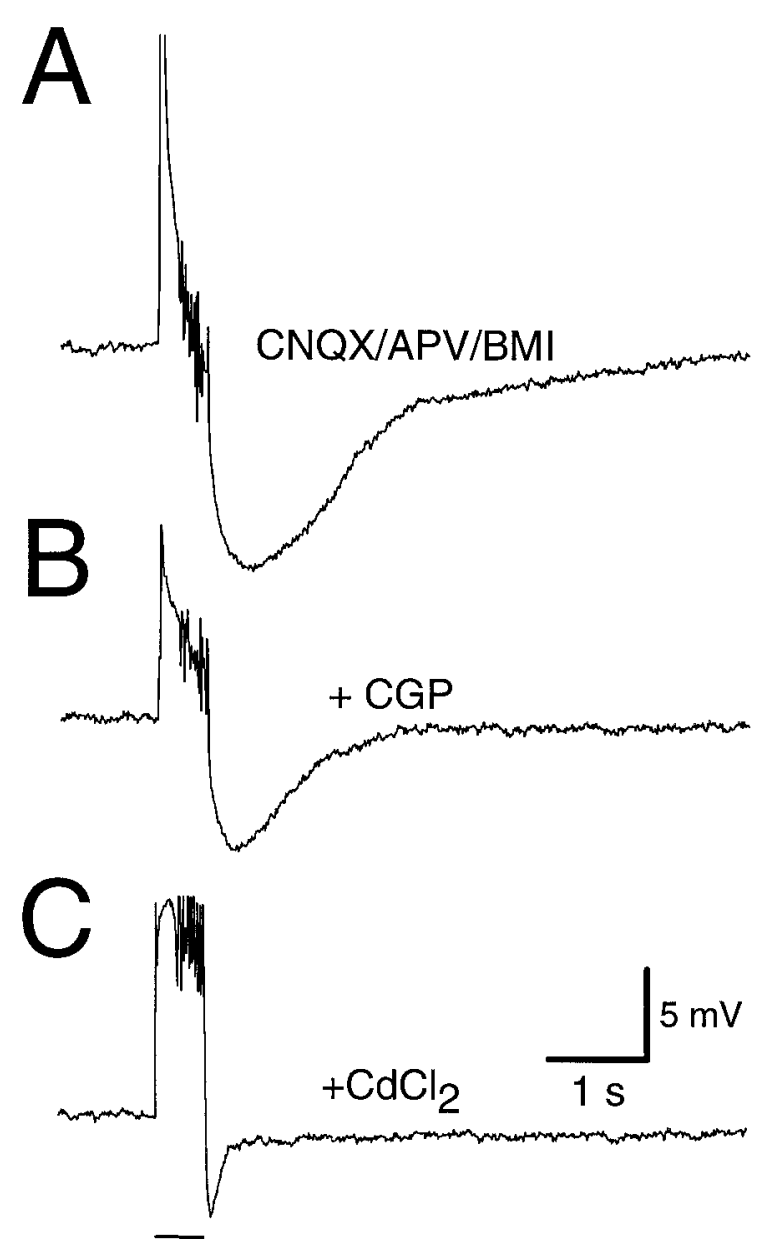

Figure 11. Contribution to the $\mathrm{SH}$ of a $\mathrm{GABA}_{\mathrm{B}}$ receptor-independent IPSP. $A$, Sample traces showing the presence of an $\mathrm{SH}$ in the presence of our standard pharmacological mixture of CNQX $(20 \mu \mathrm{M})$, APV $(100 \mu \mathrm{M})$, and BMI $(40 \mu \mathrm{M})$. Stimulus train consisted of 50 pulses at $100 \mathrm{~Hz}$, at the time indicated by the horizontal bar below the trace in $C$. B, Addition of CGP 35348 significantly reduced the magnitude of the SH. $C$, To investigate the nature of the remaining $\mathrm{SH}$, the inorganic calcium channel blocker $\mathrm{CdCl}_{2}(100 \mu \mathrm{M})$ was added to block all synaptic transmission. Addition of $\mathrm{CdCl}_{2}$ reduced the response to electrical stimulation. The small remaining hyperpolarization was caused by a calcium-insensitive sAHP produced by stimulation-induced antidromic action potentials. In this particular neuron, stimulation caused 38-40 action potentials. All records are from the same cell.

added to the pharmacological mixture. The calcium channel blocker reduced the $\mathrm{SH}(75 \pm 29 \% ; n=5)$ (Fig. 11C), suggesting that a significant portion of the $\mathrm{SH}$ is attributable to a $\mathrm{GABA}_{\mathrm{B}}$ receptor-independent IPSP. In some cases, a small, brief, residual hyperpolarization remained after the addition of $\mathrm{CdCl}_{2}$ (Fig. $11 C$ ). This hyperpolarization may have been caused by a calciumindependent sAHP attributable to stimulus-induced antidromic action potentials and could be blocked by subsequent addition of TTX (data not shown).

\section{DISCUSSION}

We have described an unusually slow, activity-induced hyperpolarization in neurons of nucleus $\mathrm{HVc}$ in the adult zebra finch. At least three components contribute to the $\mathrm{SH}$ to varying degrees: (1) an afterhyperpolarization intrinsic to the neuron recorded, (2) a synaptically induced, $\mathrm{GABA}_{\mathrm{B}}$ receptor-mediated response, and (3) an unidentified slow IPSP. All three components appear to depend on increased potassium conductance and individually or collectively may play an important role in gating information flow in the song system.

\section{Mechanism of slow hyperpolarization Intrinsic cell properties}

A component of the $\mathrm{SH}$ described here is a slow afterhyperpolarization (sAHP) caused by action potentials evoked during stimulation in HVc. These action potentials were probably evoked antidromically by stimulation of the extensive axonal ramifications of $\mathrm{HVc}$ neurons within the nucleus (Katz and Gurney, 1981; Nottebohm et al., 1982; Fortune and Margoliash, 1995). Although sAHPs are observed in most neurons studied, the sAHP observed in HVc appears to differ from those observed in most other systems (for review, see Sah, 1996). Kubota and Saito (1991) used multiple trains of action potentials to elicit an sAHP in HVc neurons having a time course similar to or longer than that of sAHPs studied in other systems. The sAHP in HVc is calcium independent and requires $\mathrm{Na}^{+}$influx. We have confirmed these findings and shown that the HVc sAHP also differs from other sAHPs, including one other known example of sodium-dependent sAHP (Schwindt et al., 1989), in its apparent insensitivity to modulation by neurotransmitters such as norepinephrine or acetylcholine (Nicoll, 1988; Foehring et al., 1989).

Although the sAHP component of the SH described here may be a consequence of our stimulation paradigm, physiological firing rates ( $\mathrm{Yu}$ and Margoliash, 1996) could produce a similar sAHP. Slow AHPs in several neuronal types mediate spikefrequency accommodation (Madison and Nicoll, 1984; Sah, 1996) and may influence stimulus-induced spike timing ( $\mathrm{Hu}, 1995)$. The particularly long time course of the sAHP observed in $\mathrm{HVc}$ neurons (typically 1-5 sec for a train of 30-50 action potentials) suggests that it may help modulate neural activity during singing.

\section{Synaptic properties}

Although we could not block the sAHP component of the $\mathrm{SH}$ selectively, we have shown that one or more slow synaptic events contribute to the $\mathrm{SH}$. In several cases, we were able to elicit a large $\mathrm{SH}$ in the complete absence of antidromic action potentials (Fig. $2 A$ ), indicating that the $\mathrm{SH}$ can be caused exclusively by long-lasting synaptic mechanisms. In addition, when antidromic action potentials were present, a substantial proportion of the $\mathrm{SH}$ could be blocked by the calcium channel blocker $\mathrm{CdCl}_{2}$. Because cadmium blocks $\mathrm{Ca}^{2+}$-dependent transmitter release and leaves the sAHP intact (Kubota and Saito, 1991; present results), these manipulations indicate that a synaptic component contributes to the $\mathrm{SH}$, even when it is accompanied by antidromic action potentials.

The SH observed here, which lasted up to $20 \mathrm{sec}$, is unusually long in duration. This slow time course is most likely caused by slow transmitter action, but if it is caused by sustained release of a short-lasting transmitter, intermediary neurons would need to continue firing after stimulation. Such neurons were never recorded in this study, and such postulated excitation would need to persist during blockade of ionotropic glutamate receptors. Alternatively, a circuit consisting of two mutually inhibitory neuronal populations could show prolonged activity (Cropper and Weiss, 1996). Such a scenario might be expected to cause rhythmic bursts of inhibition in the recorded cell. We did not observe oscillatory inhibition, however. Few IPSPs lasting seconds have been described. In most cases these appear to be mediated by serotonin (Pan et al., 1989), norepinephrine (Egan et al., 1983), or acetyl- 
choline (Dodd and Horn, 1983). Neuropeptides, although not directly shown to produce IPSPs, have been shown to hyperpolarize neurons in the CNS and may act as transmitters for slow IPSPs (Nicoll et al., 1990).

The CGP 35348-sensitive component of the SH lasts up to 20 sec and appears to require $\mathrm{GABA}_{\mathrm{B}}$ receptor activation. Although $\mathrm{GABA}_{\mathrm{B}}$ receptors typically cause IPSPs lasting only a few hundred milliseconds (Alger, 1984; Newberry and Nicoll, 1984; Dutar and Nicoll, 1988; Nicoll et al., 1990), they have been shown to mediate a tetanus-induced heterosynaptic presynaptic inhibition in the hippocampus (Isaacson et al., 1993). Because tetanic stimulation can also cause hyperpolarization in hippocampal pyramidal neurons lasting several seconds (Cole and Nicoll, 1984, their Fig. 4), these results suggest that $\mathrm{GABA}_{\mathrm{B}}$ receptors may cause slow inhibitory synaptic events lasting many seconds. However, repetitive stimulation can also cause depression of $\mathrm{GABA}_{\mathrm{B}}$ receptor-mediated responses. The long duration of inhibition observed here may reflect the stimulation paradigm or an unusually slow action of GABA on HVc neurons, possibly attributable to slow GABA uptake or a long-lasting second messenger system.

In many instances, the addition of the $\mathrm{GABA}_{\mathrm{B}}$-receptor antagonist CGP 35348 only partially blocked the SH. By blocking calcium-dependent synaptic transmission with $\mathrm{CdCl}_{2}$, without affecting the SAHP, we were able to show that this residual hyperpolarization consists of a non-GABA $\mathrm{B}_{\mathrm{B}}$ IPSP. The transmitter and receptor mediating this synaptic component remain elusive, because blockade of muscarinic (atropine), $\alpha_{2}$ noradrenergic (yohimbine), or opioid (naloxone) receptors failed to block the IPSP. Further mechanistic analysis of this IPSP is clearly required.

\section{Role of slow hyperpolarization in the song system}

Blockade of excitatory transmission by CNQX and APV consistently attenuated or abolished the $\mathrm{SH}$, indicating that a significant portion of the hyperpolarization was generated by neurons intrinsic to HVc that were synaptically excited by our stimulus. However, failure of these drugs to block the SH completely or change its slow time course suggests that monosynaptic inhibitory processes contribute to the observed SH. In this study, we cannot distinguish between monosynaptic IPSPs produced by intrinsic $\mathrm{HVc}$ neurons and connections extrinsic to HVc. Such extrinsic inputs to HVc could arise from a number of nuclei, including the thalamic nucleus uvaeformis (Uva) (Nottebohm et al., 1982), the forebrain medial portion of the magnocellular nucleus of the anterior neostriatum (M-MAN) and nucleus interfacialis (NIf) (Nottebohm et al., 1982), the HVc "shelf" (Vates et al., 1996), and possibly the field L complex (Fortune and Margoliash, 1995). Because the physiological nature of these inputs is not known, these connections could provide the excitatory input sufficient to activate inhibitory neurons within $\mathrm{HVc}$, inhibit $\mathrm{HVc}$ neurons directly, or provide a mixed excitatory/inhibitory input. The connection from Uva, and possibly NIf (Fig. 1), may be of particular interest in the context of inhibition of auditory responses during singing, because stimulation of Uva has been reported to cause long-lasting inhibition of auditory responses in HVc (Williams, 1989).

The SH often consisted of a combination of sAHP, GABA $\mathrm{B}^{-}$ receptor mediated IPSP, and a third unidentified IPSP. The relative contribution of these components to the $\mathrm{SH}$ was quite variable. In the present study, we did not attempt to estimate quantitatively the relative contributions to the $\mathrm{SH}$ made by the various component mechanisms, because these values likely depend on the details of electrode placement as well as on the class of neuron being recorded and the connections it receives. Identification of the afferent types being stimulated remains challenging because of the confluence from multiple sources. A description of the neuronal properties in $\mathrm{HVc}$ may yield interesting insight into the role of this slow inhibition. Nucleus $\mathrm{HVc}$ sends out two major projections, to area $\mathrm{X}$ and to nucleus robustus archistriatalis (RA) (Nottebohm et al., 1982), originating from separate neuronal populations (Katz and Gurney, 1981; Lewicki, 1996) that may be functionally distinct (Kimpo and Doupe, 1997). The X-projecting neurons have auditory responses (Katz and Gurney, 1981; Lewicki, 1996). We have shown here that only a portion $(\sim 60 \%)$ of all neurons recorded in $\mathrm{HVc}$ exhibit an $\mathrm{SH}$ after stimulation within HVc. Recent results (Dutar and Perkel, 1997) suggest that only X-projecting HVc neurons have the $\mathrm{SH}$, providing a clear physiological difference between these neuronal populations.

The SH observed in this study may contribute to generating song selectivity of auditory responses (Margoliash, 1983). Song-selective neurons, which respond most strongly to playback of the bird's own song, were found to become most hyperpolarized during presentation of their preferred stimulus (Lewicki, 1996; Lewicki and Konishi, 1995). This hyperpolarization was interrupted by short, precisely timed bursts of action potentials during specific segments of the song. The hyperpolarization, as well as the bursts, were absent during presentation of less favorable auditory stimuli. Hyperpolarization may permit deinactivation of voltage-dependent conductances, which are thought to cause bursting behavior in certain systems (Crunelli and Leresche, 1991; von Krosigk et al., 1993). These hyperpolarizations, which can be caused by either extrinsic (e.g., GABA $\mathrm{B}_{\mathrm{B}}$ in the lateral geniculate nucleus) (Crunelli and Leresche, 1991) or intrinsic mechanisms (e.g., sAHP in auditory thalamus) (Hu, 1995), may permit bursts of action potentials and thus provide more precise information than single action potentials (for review, see Lisman, 1996). Long-lasting, stimulusinduced hyperpolarizations may thus play a crucial role in enhancing signal-to-noise ratio by suppressing background noise, and responses to weak inputs, while allowing strong stimuli to produce precisely timed bursts of action potentials (Karlsson et al., 1990; Mainen and Sejnowski, 1995).

The $\mathrm{SH}$ could also contribute to the long-lasting inhibition of auditory responses observed during and after singing (McCasland and Konishi, 1981). Because HVc acts as a gateway for auditory information flow into the song system and because song learning requires auditory feedback, inhibition of auditory responses during singing could be regulated during song learning. It will be critical to understand whether and how inhibition in $\mathrm{HVc}$ modulates the flow of auditory information into the rest of the song system during different stages of song acquisition. Identification of the cellular basis of this inhibition as well as its development during song learning will illuminate a pivotal aspect of auditory-motor integration.

\section{REFERENCES}

Alger BE (1984) Characterization of a slow hyperpolarizing synaptic potential in rat hippocampal pyramidal cells in vitro. J Neurophysiol 52:892-910.

Alger BE, Nicoll RA (1982) Pharmacological evidence for two kinds of GABA receptors on rat hippocampal pyramidal cells studied in vitro. J Physiol (Lond) 328:125-141.

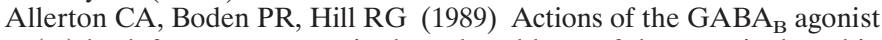
$(-)$-baclofen on neurones in deep dorsal horn of the rat spinal cord in vitro. Br J Pharmacol 96:29-38.

Andersen P, Dingledine R, Gjerstad L, Langmoen IA, Laursen AM (1980) Two different responses of hippocampal pyramidal cells to 
application of gamma-aminobutyric acid. J Physiol (Lond) 305:279-296

Andrade R (1991) Blockade of neurotransmitter-activated $\mathrm{K}^{+}$conductance by QX-314 in the rat hippocampus. Eur J Pharmacol 199:259-262.

Brenowitz EA, Margoliash D, Nordeen KW (1997) An introduction to birdsong and the avian song system. J Neurobiol 33:495-500.

Cole AE, Nicoll RA (1984) Characterization of a slow cholinergic postsynaptic potential recorded in vitro from rat hippocampal pyramidal cells. J Physiol (Lond) 352:173-188.

Connors BW, Malenka RC, Silva LR (1988) Two inhibitory postsynaptic potentials, and $\mathrm{GABA}_{\mathrm{A}}$ and $\mathrm{GABA}_{\mathrm{B}}$ receptor-mediated responses in neocortex of rat and cat. J Physiol (Lond) 406:443-468.

Cropper EC, Weiss KR (1996) Synaptic mechanisms in invertebrate pattern generation. Curr Opin Neurobiol 6:833-841.

Crunelli V, Leresche N (1991) A role for $\mathrm{GABA}_{\mathrm{B}}$ receptors in excitation and inhibition of thalamocortical cells. Trends Neurosci 14:16-21.

Curtis DR, Duggan AW, Felix D, Johnston GAR (1970) Bicuculline and central inhibition. Nature 226:1222-1224.

Davies J, Francis AA, Jones AW, Watkins JC (1981) 2-Amino-5phosphono-valerate (2APV), a potent and selective antagonist of amino acid induced and synaptic excitation. Neurosci Lett 21:77-82.

Dodd J, Horn JP (1983) Muscarinic inhibition of sympathetic C neurones in the bullfrog. J Physiol (Lond) 334:271-291.

Doupe AJ (1993) A neural circuit specialized for vocal learning. Curr Opin Neurobiol 3:104-111.

Doupe AJ, Konishi M (1991) Song-selective auditory circuits in the vocal control system of the zebra finch. Proc Natl Acad Sci USA 88:11339-11343.

Dutar P, Nicoll RA (1988) A physiological role for $\mathrm{GABA}_{\mathrm{B}}$ receptors in the central nervous system. Nature 332:156-158.

Dutar P, Perkel DJ (1997) Distinct functional properties of HVc neurons projecting to area $\mathrm{X}$ and to RA in the zebra finch. Soc Neurosci Abstr 23:246.

Egan TM, Henderson G, North RA, Williams JT (1983) Noradrenalinemediated synaptic inhibition in rat locus coeruleus neurones. J Physiol (Lond) 345:477-488.

Foehring RC, Schwindt PC, Crill WE (1989) Norepinephrine selectively reduces slow $\mathrm{Ca}^{++}$and $\mathrm{Na}^{+}$dependent $\mathrm{K}^{+}$currents in cat neocortical neurons. J Neurophysiol 62:245-256.

Fortune ES, Margoliash D (1995) Parallel pathways and convergence onto $\mathrm{HVc}$ and adjacent neostriatum of adult male zebra finches (Taeniopygia guttata). J Comp Neurol 360:413-441.

Gahwiler BH, Brown DA (1985) GABA $_{\mathrm{B}}$-receptor activated $\mathrm{K}^{+}$current in voltage-clamped CA3 pyramidal cells in hippocampus. Proc Natl Acad Sci USA 82:1558-1562.

Honoré T, Davies SN, Drejer J, Fletcher EJ, Jacobsen P, Nielsen FE (1988) Quinoxaline-diones: potent competitive non-NMDA glutamate receptor antagonists. Science 241:701-703.

Hu B (1995) Cellular basis of temporal synaptic signalling: an in vitro electrophysiological study in rat auditory thalamus. J Physiol (Lond) 483:167-182.

Isaacson JS, Solis JM, Nicoll RA (1993) Local and diffuse synaptic actions of GABA in the hippocampus. Neuron 10:165-175.

Jan LY, Jan YN (1982) Peptidergic transmission in sympathetic ganglia of the frog. J Physiol (Lond) 327:219-246.

Karlsson G, Schmutz M, Kolb C, Bittiger H, Olpe HR (1990) GABA receptors and experimental models of epilepsy. In: $\mathrm{GABA}_{\mathrm{B}}$ receptors in mammalian function (Bowery NG, Bittinger $\mathrm{H}$, Olpe HR, eds), pp 349-365. New York: Wiley.

Katz LC, Gurney ME (1981) Auditory responses in the zebra finch's motor system for song. Brain Res 221:192-197.

Kimpo RR, Doupe AJ (1997) FOS is induced by singing in distinct neuronal populations in a motor network. Neuron 18:315-325.

Kubota M, Saito N (1991) Sodium- and calcium-dependent conductances of neurones in the zebra finch hyperstriatum ventrale pars caudale in vitro. J Physiol (Lond) 440:131-142.

Lewicki MS (1996) Intracellular characterization of song-specific neurons in the zebra finch auditory forebrain. J Neurosci 15:5854-5863.

Lewicki MS, Konishi M (1995) Mechanisms underlying the sensitivity of songbird forebrain neurons to temporal order. Proc Natl Acad Sci USA 92:5582-5586.

Lisman JE (1996) Bursts as a unit of neural information: making unreliable synapses reliable. Trends Neurosci 20:38-43.

Madison DV, Nicoll RA (1982) Noradrenaline blocks accommodation of pyramidal cell discharge in the hippocampus. Nature 299:636-638
Madison DV, Nicoll RA (1984) Control of the repetitive discharge of rat CA1 pyramidal neurons in vitro. J Physiol (Lond) 354:319-331.

Mainen ZF, Sejnowski TJ (1995) Reliability of spike timing in neocortical neurons. Science 268:1503-1506.

Margoliash D (1983) Acoustic parameters underlying the responses of song-specific neurons in the white-crowned sparrow. J Neurosci 3:1039-1057.

Margoliash D, Konishi M (1985) Auditory representation of autogenous song in the song system of white-crowned sparrows. Proc Natl Acad Sci USA 82:5997-6000.

McCasland JS (1987) Neuronal control of bird song production. J Neurosci 7:23-39.

McCasland JS, Konishi M (1981) Interactions between auditory and motor activities in an avian song control nucleus. Proc Natl Acad Sci USA 78:7815-7819.

Mooney R (1992) Synaptic basis for developmental plasticity in a birdsong nucleus. J Neurosci 12:2464-2477.

Newberry NR, Nicoll RA (1984) A bicuculline-resistant inhibitory postsynaptic potential in rat hippocampal pyramidal cells in vitro. J Physiol (Lond) 348:239-254.

Nicoll RA (1988) The coupling of neurotransmitter receptors to ion channels in the brain. Science 241:545-551.

Nicoll RA, Malenka RA, Kauer JA (1990) Functional comparison of neurotransmitter receptor subtypes in mammalian central nervous system. Physiol Rev 70:513-565.

Nixdorf BE, Davis SS, DeVoogd TJ (1989) Morphology of Golgiimpregnated neurons in hyperstriatum ventralis, pars caudalis in adult male and female canaries. J Comp Neurol 284:337-349.

Nottebohm F, Stokes TM, Leonard C (1976) Central control of song in the canary, Serinus canarius. J Comp Neurol 165:457-486.

Nottebohm F, Kelley DB, Paton JA (1982) Connections of vocal control nuclei in the canary telencephalon. J Comp Neurol 207:344-357.

Olpe H, Karlsson G, Pozza MF, Brugger F, Steinmann M, Van Riezen H, Fagg G, Hall RG, Froestl W, Bittiger H (1990) CGP35348: a centrally active blocker of GABA $^{\mathrm{B}}$ receptors. Eur J Pharmacol 187:27-38.

Pan ZZ, Colmers WF, Williams JT (1989) 5-HT-mediated synaptic potentials in the dorsal raphe nucleus: interactions with excitatory amino acid and GABA transmission. J Neurophysiol 62:481-486.

Pepper CM, Henderson G (1980) Opiates and opioid peptides hyperpolarize locus coeruleus neurons in vitro. Science 208:394-396.

Perkel DJ, Nicoll RA (1993) Evidence for all-or-none regulation of neurotransmitter release: implications for long-term potentiation. J Physiol (Lond) 471:481-500.

Pittman QJ, Siggins GR (1981) Somatostatin hyperpolarizes hippocampal pyramidal cells in vitro. Brain Res 221:402-408.

Sah P (1996) Calcium-activated K currents in neurones: types, physiological roles and modulation. Trends Neurosci 19:150-154.

Schwindt PC, Spain WJ, Crill WE (1989) Long-lasting reduction of excitability by a sodium-dependent potassium current in cat neocortical neurons. J Neurophysiol 61:233-244.

Staley KJ, Soldo BL, Proctor WR (1995) Ionic mechanisms of neuronal excitation by inhibitory GABA $_{A}$ receptors. Science 269:977-981.

Vates GE, Broome BM, Mello CV, Nottebohm F (1996) Auditory pathways of caudal telencephalon and their relation to the song system of adult male zebra finches (Taeniopygia guttata). J Comp Neurol 366:613-642.

Vicario DS, Yohay KH (1993) Song-selective auditory input to a forebrain vocal control nucleus in the zebra finch. J Neurobiol 24:488-505.

von Krosigk M, Bal T, McCormick DA (1993) Cellular mechanisms of a synchronized oscillation in the thalamus. Science 261:361-364.

Vu E, Lewicki MS (1994) Intrinsic interactions between zebra finch $\mathrm{HVc}$ neurons involve NMDA-receptor activation. Soc Neurosci Abstr 20:166.

Vu ET, Mazurek ME, Kuo YC (1994) Identification of a forebrain motor programming network for the learned song of zebra finches. J Neurosci 14:6924-6934.

Wagner EJ, Moore KE, Lookingland KJ (1994) Neurochemical evidence that AMPA receptor-mediated tonic inhibition of hypothalamic dopaminergic-neurons occurs via activation of inhibitory interneurons. Brain Res 660:319-322.

Williams H (1989) Multiple representations and auditory-motor interactions in the avian song system. Ann NY Acad Sci 563:148-164.

Williams JT, Egan TM, North RA (1982) Enkephalin opens potassium channels on mammalian central neurons. Nature 299:74-77.

Yu AC, Margoliash D (1996) Temporal hierarchical control of singing in birds. Science 273:1871-1875. 